
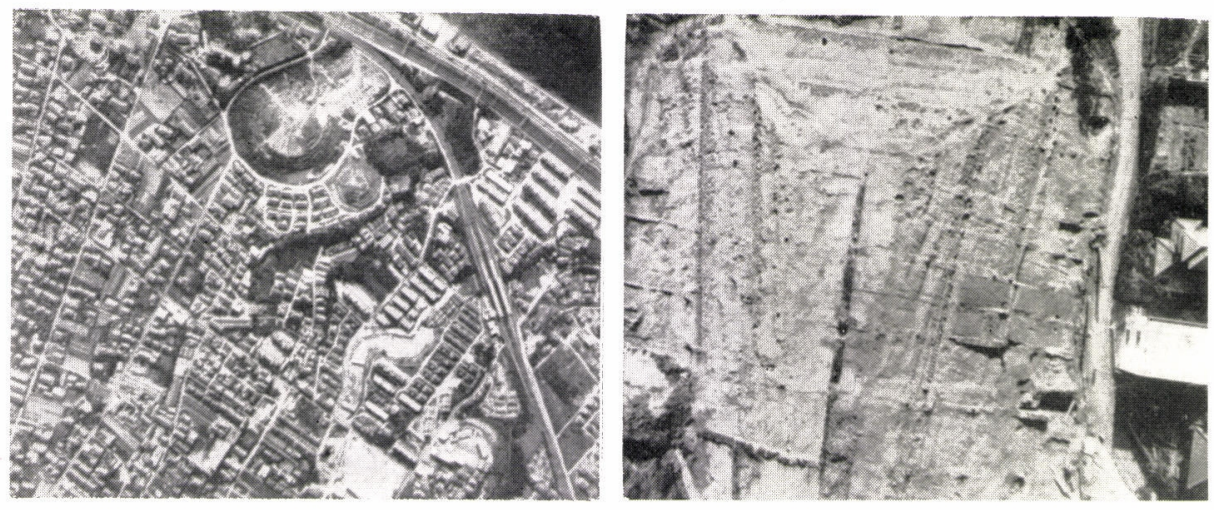

Archeological Surveys

\author{
あたらしい発展のために \\ 一第 14 回国際写真測量学会報告——
}

第11回国際写真測量学会は，1968年 7 月 8 日(月) 氻 ら19日(金)まで，スイス国ローザンヌ市のパレ・デ・ ボリューで開催された。参加国は63, 参加者は同伴者 圭含めて 760 名。前回とくらべて, 国の数では增加し， 参加者数では期待を下まわる数字であった。あらたに ソ連の代表が参加し，一方ではドル防衛の影響をうけ て，米国の軍官関係者の参加が著しくすくなかったの が印象的であった。参加者のなかには世界の写真測量 学界をになう大家や新進の顔か数多くみられたが，反 面，政治的には全くニュートラルなスイスにすら，代 表在派遺できなかった中国，ビルマ，マラヤ，エジプ ト，インド，イラク，シリア，ルクセンブルグ, チリ， スーダンといった国为あった(表参照)。

ここでは会議の全般について，その概況をつたえ， 今後の日本写真測量学会の問題の処理のための資料と したい。

定かんの改訂 か叔てから定かん改訂委員会が検討 していた新定かん案が，第1日の（8日）の代表者会議 に上程され，意見交換のあと，文章を中心とした改善 を任務とする定かん成文委員会の設置と，現委員会が 会期終了まで責任をとるへしという2 つの付带条件を 付して採択され，9 日の総会で報告決定をみた。

定かんの和英両文は何れ学会誌に掲載されようが, 要点は下記のと抢りである。

(1) 国際会議の開催, 科学的研究の促進, インター ナショナル・アーカィブの出版, オフィシアル・ ジャーナルの刊行, ナショナルソサェティーの設
丸安隆和・中野尊正

置, 科学的情報の交換などの方法により, 目的を 達成する。

(2) 各国の学会をもって構成するが，学会のない時 にはしかるべき機関をもってかえる。

(3) メンバーソサエティーを会員数によって，1８ のカテゴリーにわけ，各カラ゙ゴリーごとに会費の ユニット数をきめる。（スイス会議で 1 ユニット は30スイスフランと決定）ユニットは随時あげる ことはできるが，総会の議をへなければへらすこ とはできない。

(4) 部会の活動を活発にする。

（5）代表は 1 名, アドバイザーは 2 名まで代表者会 議に参加できる。たたしじートは 1 名に限定され る。

（6）カウンシルは総会において選任された会長，会 議議長, 2 人の副会長, 事務総長, 経理長をもっ て構成する。退任会長は自動的に副会長になる。 しかし引退の場合には，退任事務総長，退任副会 長(ただし会長歴のない者), 退任経理長, 退任会 議議長の順に副会長の 1 人をきめる。これでも駄 目な場合には選挙によってきめる。

（7）公用語は英, 仏, 独の 3 力国語とし, 会議主催 国の経理的責任において，自国語の通訳をするこ とができる。

全般圭通じていえることは，政治的なノンディスク リミネーションを強調して打り, 欧米中心の学会活動 を,さらに広い地域にひろげ,この分野のあたらしい 
発展をねらっている。

新加盟国 1964～68年間にあらたに加盟を認められ たのはアアルジェリアの国防省国立地図研究所，才一 ストラリア写真测量学会, ブルガリア测地学科学技術 連盟, キューバ測地学地図学研究所, リビアの企画開 発省測量地図局，シリア軍地図局，夕イ王国測量局の 7 つであり,さらにり連写真测量学者委員会とメキシ コ写真測量学会の 2 つが代表者会議で承認され，総会 において決定された。

ペルーの国立工科大学地形測量学測地学研究室の申 込みについては，あたらしい定かん第12条にしたがっ てその定かん, 目的, その国における状況, 写真测量 学に関する他の機関との関係, 事務組織, 財政につい ての報告を検討したうえで決定することになった。

財政 4 年間の会計報告について報告があったが， 最終的には会議報告をまたないと決算できないという ことで報告を承認した。この時, どの学会でやるよ うに，未納会費の催促が抗こなわれ，最近 2 年間の未 納国の名前がよみあげられた。ブラジルはその場で小 切手を差出し，拍手をあびた。日本めよみあげられた が，支払、済みと思いこんでいたし，準備もしていな かったので小さくなっ ていた。

会費はユニット数に したがってきめられる が，それをきめる力テ ゴリーは学会会員数に よっている。日本は, 100 名で登録している が, “100 名の会員て 19名为ススまで来る とは”とひやかされ た。どうもこの際会員 数を訂正して分類を正 当に支払うこと在考え ねばなるまい。会員数 25までは 1，26〜50が が 2, 51〜150 が 3, 151〜250が 4, 251〜 400 が 5, 401〜600が 6, 601 800が 8,800以 上が 8 となっている。

他の国の会員数と会 議出席者起見ると, 近 国では $1 / 10$ 程度, 力 ナダ・米国て $1 / 40$ 程
度, ブラジルで $1 / 100$ 程度であり, 日本の $1 / 20$ はヨ ーロッパ諸国なみであったから，疑問をもたれて当然 であろら。

会議主催国 1972年については, 今回の直前のサー キュラーによって, カナダ測量研究所が，会議議長予 定者として S.G. ギャンブルを指名し, オタワ大学の 新らしい建物をつかって開催したい旨の申入れをして いたことが判明していた。カナダ以外の国の申入れが あるかどうかが討論の焦点であったが，ついにどの国 から女申入れがなく, カナダが1972年の会議主催国と なること， S.G. ギャンブルが会議議長になることが 決定され，総会で承認された。

ところで, 1976年についてはすでにフィンランドが, ヘルシンキに近いオタニエニの国際会議場をつかい, K.G.レフトストレムを会議議長予定者として招請し たいと申入れていた。この件が紹介されると，米国代 表はすかさずこれ支持し，「もしその時点において， フィンランド周辺の水が污染されていたら, 米国が肩 代りしたい旨の発言があった。フランス代表ジャン・ クルゼーは米国の発言は妥当でないと反論し，また力 ナダからは1968年の時点で決定することには無理があ るから，1972年の会議の数力月前に，何等かの法で
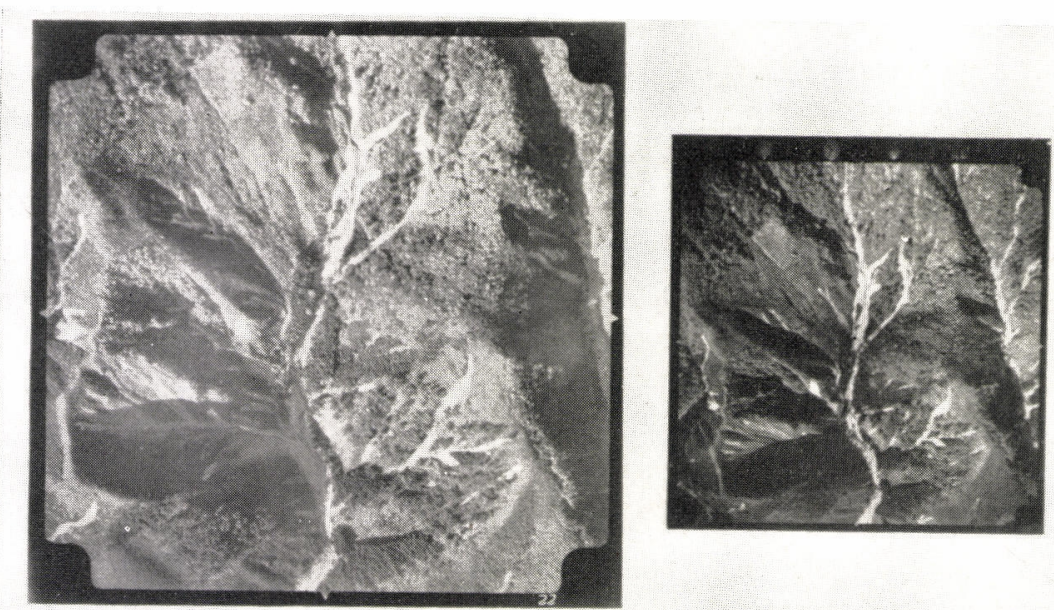

\section{TYPHOON DISASTER}

SAlkO (one of the 5 Full Lakes) district were attacked by a gigantic typhoon on oct 1966.

The subsequent mud flow kiled many residents.

\begin{tabular}{|c|c|c|}
\hline & Cwher & Biach \& whule \\
\hline Camera & RC $-8 f-151.88$ & RC 8 t -200.56 \\
\hline Fliglt: altitude & $1,800 \mathrm{~m}$ & 2.050m \\
\hline Brser Level & $1.050 \mathrm{~m}$ & $1.000 \mathrm{~m}$ \\
\hline
\end{tabular}




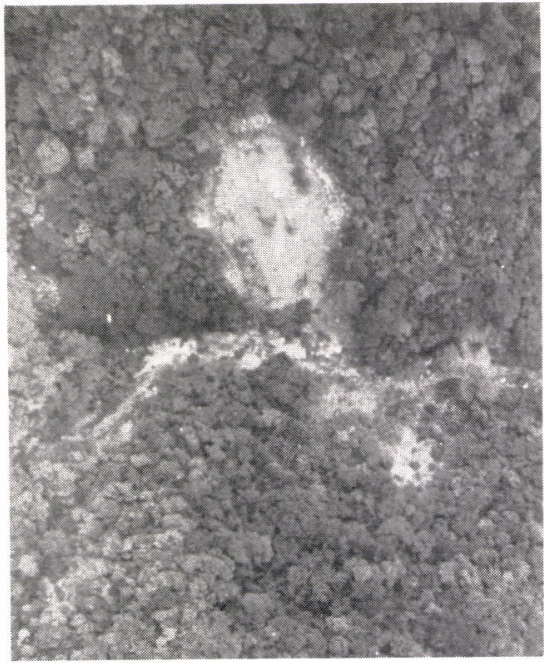

Land Slide and Fall Investigation

(図他略)

きめてはどうかと提案した。カナダの発言をうけて， ファーゲルホルム (副会長) は, 何等かの方法の一つ として, 会長加各国へ手紙を出し, 返事を斗らうと いった方法在とれないかと発言した。ブラジルは「南 半球ではまだ一度も開催されていないし, ブラジルに も会議開催の意志があること」を強調した。ブルガり アも意志を表明して，1976年の主催国については，に わかに活気づいたのである。

日本の去就か当然問題になったが, 会議中, 日本で の開催を考虑するようにとの干涉は全くなかった。た だ後述の役員選出の詿論をきくに抢よんで，日本が自 主的に国際写真测量学会の趣旨にのっとって, 何らか のコントリビューションを継続するような形での結論 を出して打くべきではなかったかと痛感した。この意 味では，会議前に理事会において決定した「どんな形 の協力も引うけない上うに」といった趣旨の結論は， 反省されてしかるべきであろう。

丸安・中㽥の両名は, 代表者会議での発言を検討し， たまたま立寄られた青野氏(パシフィク航業)の意向を うかがったが，何らかの形で1976年の主催予定国の一 つに名のり出ることについて, 積極的な賛成はえられ なかった。そこで,「文書をもって意志表示のこと」と いうへリー会長の指示にしたがって，参加者の意見も 徵して代表の責任において，開催の意志のあることを 表明してきた。

この結果，1976年に関しては,「フィンランド写真測 量学会がよく整備された組織, 会場などを準備して, 1976年の主催国たる用意がある」旨の記録とともに， 「1976年求よびその後の国際会議の招待がブルガリア， 米国、日本，ブラジルからあったことを記録にとど女
る」ということに決定し, 総会において報告了承され た。

後述の役員選出でふれるが，新役員の顔ぶれをみる と, 1976年のフィランドはかなり決定であり, フィン ランド以外の国がこの条件のもとてどのような態度を とって行くべきかについての意向在決定することが必 要と判断される。

役員の選出 役員の選出は新定かんにしたがってお こなわれる。したがって, 会長は会議主催国以外から 選出されてもよいことになる。カナダが主催国と決定 したので, 会議議長は S.A. ギャンブル局長ときまっ た。また退任会長を引退する場合には, 上記の規定に したがって，退任事務総長が副会長として残留する。 ヘリー会長が高令のため引退を表明したので, かわっ てバックマン教授が第 1 副会長に決定した。会長には ミラノ工科大学 D.L.ソライニ教授がえらばれ, 決定 した。

残る第 2 副会長, 事務総長, 経理長をめぐって, 各 国のうごきが活発になった。米国は会議開催前に，文 書をもって副会長を要請しており， G.C. トウウィン ケルが推せんされていた。これに対して，フランスも 1つのポス卜を要請し，北欧諸国を代表して，スウェ ーデンのテルンリドが S.R. ハローネン教授を推せん した。さらに会長は,わざわざたとえばとことわって， 退任する第 4 部会長の L. スクラダールとか, フィリ ッピンの代表といった人を候補にあげてはと示唆し, 自せん他せんを潘のめかしていた。

役員の推せんにみる各国の意欲はきわめて明白であ り，他せんをまって役員になりうると考えることは， 特別な場合をのぞいてはありえないことがはっきりし た。最終決定は, L.スクラダール, J.クルゼー, S.R. ハローネン，G.C.トゥウィンケルの4名について投 票できめるということになり, スクラダールが J. ク ルゼーを僅差で破って，S.R. 八ローネン，L．スクラ ダール, G.C. トゥウィンケルの 3 名が決定した。こ のうち，八ローネンは大家として知られて抢り，他の 2 名は68年までの部会長として実績のあった人及であ り，実績が如何に物をいうかを示したともいえよう。 またともに年令はわかく, 将来の発展を期しての人事 であったとみることもできよう。日本はおしいチャン スをにがしたともいえる。

この点は, 後述のコミッション担当国決定の際の討 論にもあらわれており, 米国は第 3 部会のセクレタリ ー M.B.シェアーがあらたに第 1 部会の委員長として 打出している。

部会担当国の決定 部会, ワーキング・グループ, インターコミッションが科学技術的活動の中心をなす 


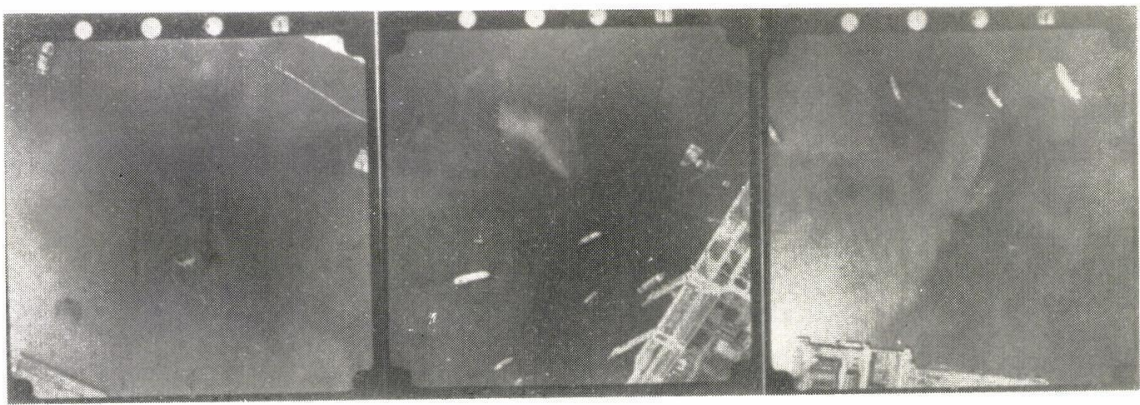

Pre-Investigation of Chemical Kombinat Locationing

と考えているから，部会担当国の決定は，いわば各国 の研究水準, 研究意欲在示す場ともいえる。会談前の サーキュラーでは, 第 1 部会には希望国がなく, 第 2 部会には西ドイッ，第 3 部会にはイギリス，第 4 部会 には米国，第 5 部会にはオーストラリア，第6 部会に はチェコスロバキア，第７部会には東ドイツが希望を 表明していた。

ブラジルは第 8 部会を新設, マルチ・リモート・セ ンシングに関する研究を推進すべきことを主張した が，この提案は新カウンシルが検討することにして， 今回は実現されないことになった。そこでブラジルは 第 1 部会へのりかえ, スウェーデン, 米国も第 1 部会 を希望した。第 3 部会にはイタリアの希望が出され， 第 4 部会にはフランス，オランダ，第 5 部会にはフラ ンスが名乘りをあげた。第 6 部会には東ドイッ，第 7 部会にはオーストラリアが希望が表明したが，すぐあ とでオーストラリアは加盟後日が浅いので今回は辞退 したいと申入れたため, 第 5 部会はフランスのみ，第 7 部会は東ドイッのみになった。

カウンシルての討論の末，第 1 部会は米国（委員長 は M.B.シェアー), 第 2 部会は西ドイツ(デーカー),

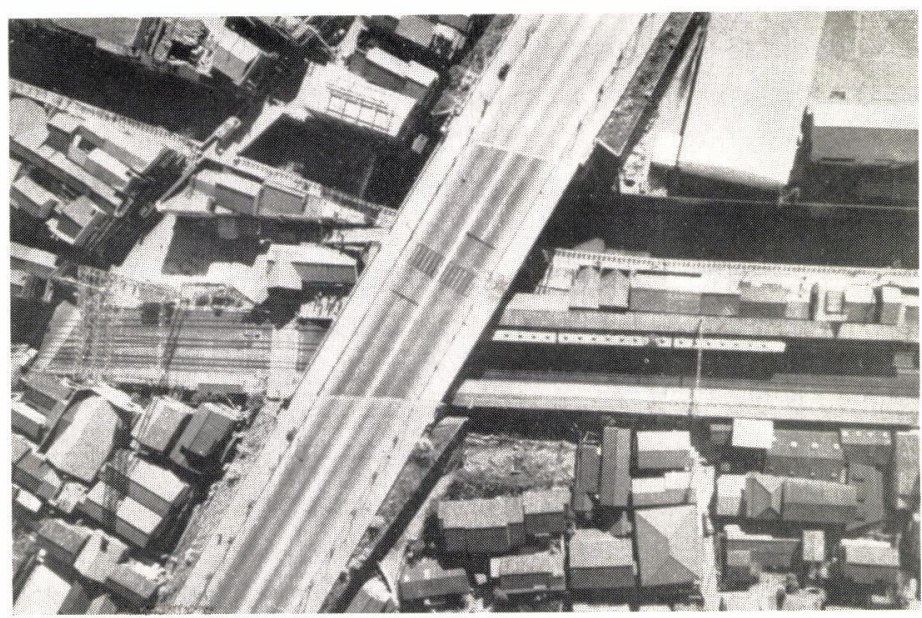

Helicopter Puotogrammtry

(図他略)
第 3 部会はイギリス (E.トムソン)，第 4 部会はオラン ダ(ファンデル・ヴェーレ), 第 5 部会はフランス $(M$. カーボネル), 第 6 部会は P.ガル (チェコスロバキア), 第7 部会は東ドイッ(A. ラインホルド) と決定, 総会 に報告了承された。

部会担当国は科学技術の発展のうえで責任は重い が，先進各国の担当しよう，担当したいという意欲は きわめて明白であり, 強烈であった。日本はここです, 担当国たるのチャンスを失ってしまった。とくに，討 論をきいていて, 第 6 部会, 第 7 部会の担当者として の可能性はきわめて高かったといってよい。

76年の総会招請がかならずしも容易ではないことを 考えると，72～76年には部会を1つ担当し，副会長を 1 人確保することを目標に, 学会の体質強化が必要で あろう。またこの位のコントリビューションを現在の 日本としては当然果すべぎあるし，こうしてはじめ て，国際会議に10名以上が参加する実質的資格がもて るといってよいであろう。

定かんと財政に関する委員会 定かんは採択された が，文意をそこなわない範囲で，定かん最終成文を検 討する委員会の設置は, 定かん抢よび付則採択の付帯 条件であった。カウンシルで討議の 結果，代表を. $\mathrm{H}$ ヘリ一，英語担当 R.LI. ブラウン, フランス語担当 J. クルゼー，ドイッ語協力者 G. クラ ウスと決定した。

財政委員会は, A.P.クレメンテ, J.E.オドル, S.G.メラーの 3 名で構 成されることになった。

定かん拈よび財政にも関係をもつ セントラル・アーカイブの刊行の可 能性を検討する件は, W. スケマホ ーン, H.ヘリー, A.P. クレメンテ の 3 名を中心とし，さらに協力をよ びかけることになった。この検討の 必要性は, 代表会議で討論され, 会 

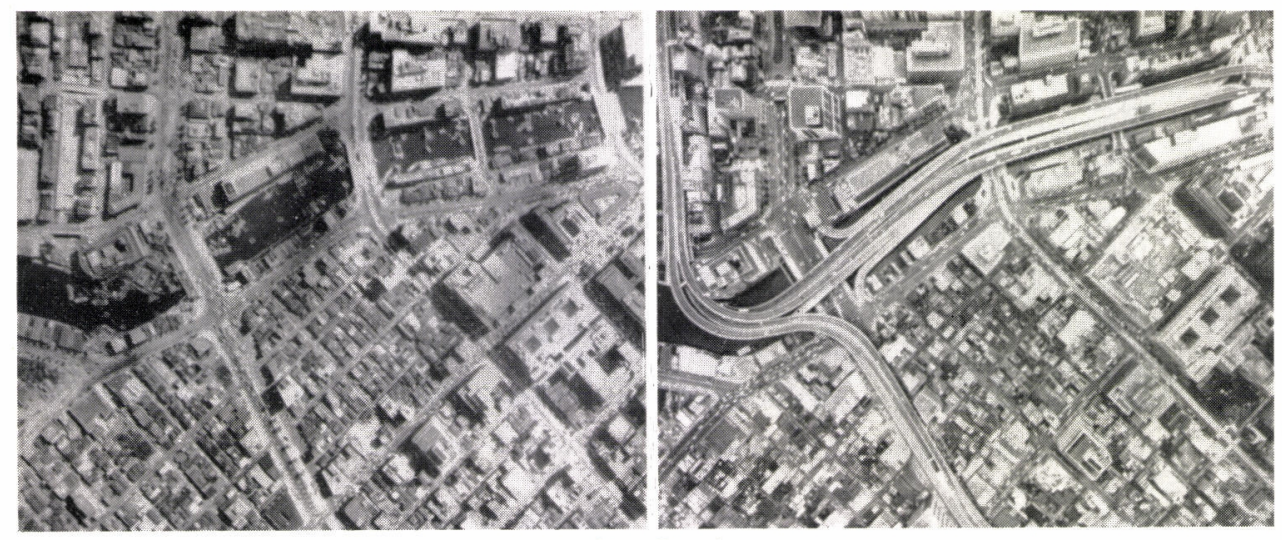

City Development

議後あるいはシンポジアムのあとに刊行されるアーカ イブに対して，また公的刊行物たるフォトグラメトリ アに対して, 別の出版物を国際写真測量学会としても つベきではないかというスケマホーンの提言に発して いるが, この点は後述のフォトグラメトリアの現況と の関連において議すべきであろう。

各国提案とその処置 総会には，加盟国から全体に 関係する間題を提案し, 代表者会議の議をへたあと適 宜その処置が決められることになっている。今回も, ブラジルが第 8 部会をもうけ, マルチ・リモート・セン シングに関する研究を推進すへきさとを提案し, フラ ンスはに゙めいつかの国がそれを支持する発言をした が, 結果としてはカウンシルにおいて検討し, 結論を 出すことになったことはすでにのべた。

イタリーの提案した空中写真, 地図等の地図学的資 料の自由な交換を促進すべきだという提案は, 各種の 制約はあるとはいえ「「科学的目的のために」という筋 をとおして，可能な範囲から踏みだすべきではないか という意見が支配的であった。この件は，カウンシ ルが「科学的目的のために, 地図学的資料老自由に配 布することの可能性を研究する」という結論に達した。

フランスは, 会議前に代表者のワーキングミーティ ングの日程をあらかじめ各国に通知し, 部会の責任業 務をあらためることについて検討するよう要請した。 これはブラジルの提案のようなものがあっても, 会期 中には憲議末了となり, 研究を扔くらせることになる という考えに基づくものであり，1971年1月までに報 告を提出するよう義務づけた研究グループの設置を求 めたものである。このフランスの提案い，各国の支持 をえて，実施についてカウンシルにゲタをあずけるこ とになった。

F.I.G と I.S.P の開催が 3 年と 4 年になっているた め, 参加のうえで, また連学のうえで不便も多いので,
1974年の F.I.G から， 2 年ごとにF.I.G と I.S.P と が交互に開催されるようにしたいというイギリスの提 案は満場一場で採択された。

フォトグラメトリア編集委員会 フォトグラメトリ アの編集委員中野が出席した。スケマホーン委員長は, フォトグラメトリアの歴史, 果してきた任務を静かに 説き, 最近, 原稿のあつまりのわるいことの原因, 対 策について意見を求められた。シンポジムや大会の 記録は別にアーカイブが出版されるため, 別にオリジ ナルペーパーをあつめることには無理があるのではな いか。判読関係の論文が各国で増大しているのに，フ ォトグラメリアではかならずしもそうではない。積極 的に判読関係の論文の投稿を求めてはどうかなど, 全 部の委員から積極的な発言があった。

中野も, 各研究機関, 各国学会誌に優先的に投稿す るのはむしろ当然であるから，この機会にフォトグラ メトリアの性格の再検討をしてはどうか? ソ連はじめ 英, 独, 仏語以外の国々の研究老積極的にあつめては どうか？また，オリジナル・ペーパーのみでなく， 会議の際の決議の背景にあるものをまとめて収録して はどうかといった内容の発言をした。

これに対して，スケマホーンはじめ $2 \sim 3$ の委員か ら, 日本の学会誌その他の刊行物には, 写真測量, 判 読に関するものが多く, 英文のあるものをみる限りき わめて魅力的で, 是非委員の 1 人として努力してほし いと協力を要請した。欧文論文のあるものが高く評価 されている例としては平井, 鍛治等の例のほか, 数例 があげられたことを指摘して扔きたい。

スケマホーンは老令を理由に引退し, かわってファ ・デル・ウェールが委員長に任命された。総会では 引退したスケマホーンに謝意をのべていたが, フォト グラメトリアとともにあゆんできた同教授に、日本か らすぐれた論文をささげたいるのである。 
若干の所見 代表者会議の話題を中心にのべたが， 最後に一つ所見をのべておきたい。国際学会で活動す るまえに, 日本の学会を整備することの必要はいうま でもないことである。このためには，目標をきめて組 織的に活動することが必要であるし，日本のいい業績 を積極的に国際学会に紹介する学をを学会としてもとる ベきであろう。1964年 9 月のユネスコ主催のトウルー ズ会議の席で, 中野が日本の業績の一部を紹介した際, フランスのギイが立って,拈どろきの声を発しながら， もっと日本の事情を知りたいと発言したのを今もよく
おぼえている。彼はこの会議において, 各国の判読関 係の論文を総点検し, 論文の内容, 数からみた1900年 以降の発展について，きわめてインストラクティブな 論文を発表したが，日本の情報が限られていたことを 痛感していたのである。

ローザンヌには第 7 部会のセクレタリーとして参加 し，積極的には日本の情報を知りたがっていたが，代 表者会議や第 5 部会との重複で, ごく一部のミーティ グの時にしか発言できなかったことを残念におもって いる。

参 加 国と 参 加 者 数

\begin{tabular}{|c|c|c|c|c|c|c|c|c|c|c|}
\hline 国 & 名 & $\begin{array}{l}\text { カテゴ } \\
\text { リー }\end{array}$ & $\begin{array}{l}\text { 参加者 } \\
\text { 数 }\end{array}$ & 分 類 & 会員数 & 国 & $\begin{array}{l}\text { カテゴ } \\
\text { リー }\end{array}$ & 参加者 & 分 & 会員数 \\
\hline Algeria & & 1 & 1 & I & & Netherlands & 4 & 60 & $\mathrm{~S}$ & 223 \\
\hline Argentina & & 1,1 & 4 & $I-2$ & & Norway & 3 & 39 & S & 146 \\
\hline Australia & & 6 & 7 & $\mathrm{~S}$ & 553 & Pakistan & 1 & 1 & I & \\
\hline Austria & & 4 & 13 & $\mathrm{~S}$ & 220 & Peru & & 2 & & \\
\hline Belgium & & 4 & 10 & $\mathrm{~S}$ & 250 & Philippines & 1 & 3 & $\mathrm{~S}$ & 25 \\
\hline Brazil & & 4 & 2 & $\mathrm{~S}$ & 417 & Poland & 3 & 10 & S & 110 \\
\hline Bulgaria & & 1 & 3 & S & & Portugal & 2 & 11 & S & 48 \\
\hline Canada & & 8 & 23 & S & 1.000 & Rhodesia & & 2 & & \\
\hline Ceylon & & & 2 & & & Roumania & 2 & 6 & S & 35 \\
\hline Colombia & & & 1 & & & Scotland & & 1 & & \\
\hline Congo & & & 2 & & & Spain & 2 & 9 & S & 25 \\
\hline Cote D'Ivoire & & & 1 & & & Sweden & 4 & 50 & S & 230 \\
\hline Cuba & & 1 & 2 & I & & Switzerland & 3 & 70 & S & 135 \\
\hline Czechoslovakia & & 2 & 16 & S & 40 & Tanzania & & 1 & & \\
\hline Denmark & & 3 & 14 & $\mathrm{~S}$ & 98 & Tasmania & & 2 & & \\
\hline Eire & & & 2 & & & Thailand & 1 & 4 & I & \\
\hline England & & 6,6 & 45 & $\mathrm{~S}-2$ & $\begin{array}{l}523 \\
492\end{array}$ & Tunisia & 1 & 4 & I & \\
\hline Ethiopia & & & 2 & & & Trinidad & & 1 & & \\
\hline Finland & & 4 & 21 & $\mathrm{~S}$ & 168 & Turkey & 9 & 8 & I & \\
\hline France & & 6 & 49 & $\mathrm{~S}$ & 500 & Uganda & & 1 & & \\
\hline Germany & & 6,5 & 72 & $S-2$ & $\begin{array}{l}446 \\
266\end{array}$ & Union of South Afica & 4,4 & 24 & $S-2$ & 226 \\
\hline Ghana & & & 1 & & & Union of Soviet Republics & 8 & 6 & S & \\
\hline Greece & & & 3 & & & United States of America & 8 & 63 & S & 4,000 \\
\hline Hong Kong & & & 1 & & & Uruguay & & 1 & & \\
\hline Hungary & & 3 & 5 & S & 85 & Venezuela & & 3 & & \\
\hline Iran & & 1 & 9 & I & & Burma & 1 & 0 & I & \\
\hline Ireland & & & 1 & & & Chile & 1 & 0 & $\mathrm{~S}$ & 25 \\
\hline Israel & & 2 & 5 & $\mathrm{~S}$ & 35 & China Republic of & 1 & 0 & $\mathrm{~S}$ & 25 \\
\hline Italy & & 5 & 25 & $\mathrm{~S}$ & 280 & Egypt, U.A.R. & 1 & 0 & I & \\
\hline Japan & & 3 & 19 & $\mathrm{~S}$ & 100 & India & 1 & 0 & I & \\
\hline Jugoslavia & & 2 & 3 & $\mathrm{~S}$ & 50 & Irak & 1 & 0 & I & \\
\hline Kenya & & & 5 & & & Luxembourg & 2 & 0 & $\mathrm{~S}$ & 30 \\
\hline Lebanon & & & 3 & & & Malaya & 1 & 0 & I & \\
\hline Libya & & 1 & 2 & I & & Sudan & 1 & 0 & I & \\
\hline Madagascar & & & 1 & & & Syria & 1 & 0 & I & \\
\hline Mexico & & 1 & 1 & $\mathrm{~S}$ & & & & & & \\
\hline Morocco & & 1 & 2 & I & & 参加者数合計 & & 760 & & \\
\hline
\end{tabular}

